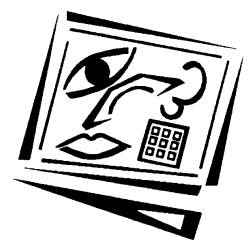

\title{
Australian undergraduates' use and ownership of emerging technologies: Implications and opportunities for creating engaging learning experiences for the Net Generation
}

\author{
Beverley Oliver and Veronica Goerke \\ Curtin University of Technology
}

\begin{abstract}
Studies and commentary from the United States suggest that current undergraduates, part of the so called Net Generation, are high end users of emerging technologies such as mobile devices and new communication tools. This paper reports results from an Australian study of first year undergraduates which confirms these assertions: ownership of laptops, mobile phones and music devices appears to be growing rapidly among this group, along with their use of tools such as instant messaging, blogs and podcasts. Discussion of these results include suggestions as to how teachers of first year undergraduates can incorporate these tools and devices into extramural learning experiences in order to increase engagement and exploit the Net Generation's desire for 'connectedness'.
\end{abstract}

\section{Introduction}

Undergraduates' "digital backpacks" are likely to hold all manner of convergent mobile devices and tools (Millea, Green, \& Putland, 2005) designed to keep the multi-tasking Net Generation connected and 'always on' (Oblinger \& Oblinger, 2005). The contents of these students' "digital backpacks" are interesting not just in themselves, but because of what they indicate about their owners' electronic habitats and the activities they find potentially engaging. Oblinger and Oblinger, drawing on studies in the United States, claim that today's Net Generation (born between 1982 and 1991, making them currently between about 14 and 23 years of age) began using computers between the ages of 5 and 8; in their teenage years, they used the Web extensively for school research (Oblinger \& Oblinger, 2005). Convenience, connection and control are claimed to be the factors driving the Net Generation's take up of information and communication technologies (Caruso, 2004), and that take up is increasing steadily (Caruso \& Kvavik, 2005). The devices likely to be found in the "digital backpack" 
are changing rapidly. Mobile phones, for example, began as voice communication tools, and rapidly became devices for text and image exchange; more recent models include built in cameras, (limited) Internet and wireless access, and the capability to play digital music files. The more sophisticated "smart" phone (almost hybrids of handheld computers) had basic office software capabilities, greater Internet capability, and a host of basic computing functions, as well as thumb and extendable keyboards (Trinder, 2005). The Apple iPhone launched in January 2007, offers all of the above and more: it combines a mobile phone, a widescreen iPod with touch controls, and a breakthrough Internet communications device with desktop class email, web browsing, maps, and searching, "completely redefining what you can do on a mobile phone" (Apple, 2007). Some commentators claimed that this was more than a smart phone, this was a brilliant phone; others were more circumspect. Regardless of whether Apple lives up to its claim to completely revolutionise the mobile phone, one thing is almost beyond doubt. Given the rate of take up of new technologies, these iPhones will be part of the digital backpacks of many university students soon after they become available.

Unlike most of those who teach them, university students today are often "more comfortable working on a keyboard than writing in a spiral notebook, and are happier reading from a computer screen than from paper in hand" (Frand, 2000). Consequently, it is often the more interactive Web 2.0 applications enabled by these devices that younger users find more attractive. Instant messaging, with more recent features such as voice chat, video conversation, shared whiteboard spaces, application sharing, and remote assistance or control of the computer by another (Millea, Green \& Putland, 2005), is often preferred by younger users who nowadays tend to consign email to formal contexts such as communications with teachers and parents (Oblinger \& Oblinger, 2005). Similarly, the Web 2.0 application generically known as blogs are popular with the young-they are personal, group or corporate web based journals which can be produced from a desktop as well as a mobile phone. Podcasting is also a growing phenomenon. It can be accessed "on the go": any computer user with a microphone can prepare an audio file for podcasting and make it available for search, exchange, and retrieval by other users (Millea, Green \& Putland, 2005).

Overall, Web 2.0 is "all about moving beyond content delivery to personal publishing, ease of use, interactivity, collaboration, sharing, and customisation" (Cochrane, 2006). These features are increasingly available on devices which are mobile (in the sense that they can be used on the move): common examples are laptops, handhelds, mobile phones and music playing devices. In this paper, a handheld computer is understood as a personal digital assistant (such as a Palm Pilot) which is "a small, 
mobile device that provides computing and information storage and retrieval, and that can be easily carried and used" (Deneen, 2001), with the acknowledgement that since this definition appeared in the literature many convergent devices offer these capabilities and more.

Teaching and learning innovations are best implemented when informed by learning theory (Cochrane, 2006). The pedagogical framework based on student achievement of learning outcomes (Huba \& Freed, 2000) leads teachers to ask seminal questions about how students can best achieve specific learning outcomes: what are the learning outcomes and how will they be assessed; what type of interactive learning experiences are most likely to engage students and enhance their achievement of the intended outcomes? The answers to these questions can also be guided towards enhancing student learning by encouraging communities of practice (Wenger, 2002). The combination of mobile devices and Web 2.0 social software go some way to assist the development of communities of practice and beyond: learning assisted by sophisticated tools such as those discussed here are closer to a model of communication than a model of dissemination (Heppell, 2002) which go beyond interactive to participative, allowing learners not to just to consume and interact but to truly construct knowledge (Cych, 2006; Heppell, 2002). Potential participative activities using the devices and communications tools discussed here are:

- Instant messaging applications might facilitate discursive on and off campus activities, such as group work, discussion, and collaborative problem solving. The interactive whiteboard feature is particularly suited to problem solving activities. The fact that so many university students are already active users of instant messaging (about 4 out of 5 in the studies reported here) means that this technology could be easily included in suggested learning activities outside the physical classroom, and outside the restrictions of traditional learning management systems such as Blackboard and WebCT.

- Blogs encourage student reading and writing, and can be used to elicit feedback and review learning materials and professional papers as well as enable the exchange of views and opinions (Millea, Green \& Putland, 2005). Students involved in artistic, musical or other creative units could also benefit from 'displaying' or sharing their work (especially non-text) in blog spaces. When blogs are made public (as many are), students can interact with "guest contributors" (even published experts in the field) who visit and comment on their posts. This could be an advantage of blogs over discussion boards currently housed behind restricted sites within institutional learning management systems. Public blogs used by groups of students allow joint authorship, and teachers may view progress at anytime. Wikis, like blogs, are web based publishing 
systems enabling anyone to update or change the content of a site; they can be used to support collaborative learning activities, and enable students to develop content in group situations (Millea, Green \& Putland, 2005). Really Simple Syndication (RSS) is likely to be used by bloggers: it enables automatic updates from sites (such as other blogs and news and information resources). It is quickly becoming a "must have" technology for those who need current information ("RSS (file format)", 2005). Lecturers might consider creating RSS feeds for their courses, so that students will be alerted when updates are made.

- Audio technologies such as podcasting tend to continue to be one way communication modes: they enable listening. Nevertheless, podcasting is being embraced by institutions such as Stanford University which now makes aural events (lectures, audiobooks, music) available to the public through free podcasting software (Stanford University, 2005). Students can create their own podcasts and share them online with peers and the wider community.

Studies from the United States suggest that the young are prolific users of the tools and devices described here (Caruso, 2004; Caruso \& Kvavik, 2005; Oblinger \& Oblinger, 2005). The conundrum for Australian university educators, however, is whether enthusiastic reports from the US in relation to college students' technology habits are as applicable in Australia, and if so, how might this be taken into consideration when teachers attempt to engage these "Net genners" in learning. Recent research findings appear to concur with the US studies: research from Melbourne found that Australian students are enthusiastic about device ownership and use (Kennedy, Krause, Judd, Churchward \& Gray, 2006). The findings from that study are echoed in the research reported here: this study, conducted with incoming university students in Western Australia, examines beginning undergraduates' levels of Internet access, device ownership and use of emerging tools for social as well as for study purposes. The study examined these factors in two cohorts: the first (Business and Engineering students) in 2005, and the second (Engineering students) in 2007. The analysis of results notes changes in student behaviour in the two cohorts. The findings are considered in the light of the potential impact this has on attempts to engage students in Australian undergraduate classrooms.

\section{Method}

The first cohort was surveyed in August 2005: a questionnaire was developed as part of an initial data gathering exercise in relation to a mobile learning project (Oliver \& Barrett, 2004). The survey was administered to first year undergraduate students attending tutorials in two units of study (a Business unit and an Engineering unit) during the 
first week of second semester at Curtin University of Technology in Western Australia. Apart from gauging student interest in participating in the mobile learning project, the survey canvassed student characteristics in three main areas: (1) their access to the Internet outside university and whether they used online resources to help with learning; (2) their ownership of laptops, handhelds, mobile phones and music devices; and (3) their use of emerging communications tools such as Short Messaging Service (SMS), Multimedia Messaging Service (MMS), instant messaging, blogging, mobile blogging, VoIP and podcasting. Students were assured that some of these technologies might well be unknown because they were relatively new. A similar survey was administered in February 2007. It canvassed the same three aspects of students' access, ownership and use of applications, with refinements included in the light of the results from the first survey: these focussed on the students' use of devices and applications for study purposes (as well as socialising). The survey was administered to incoming first year undergraduate students in an Engineering unit in first semester at Curtin University of Technology in Western Australia. The full text of pertinent items in both surveys appears in Appendix 1.

Because the surveys were administered in different circumstances, the two cohorts were rather different. In 2005, 413 students completed the survey; three quarters $(76.8 \%)$ were enrolled in a Business unit and the remainder were enrolled in an Engineering unit. As shown in Table 1, nearly twothirds were male $(62.3 \%)$, just over two-thirds $(69.5 \%)$ said their first language was English and the vast majority (88.6\%) were between 17 and 25 years; just over half (55.2\%) were between 17 and 20. In 2007, 290 engineering students completed the survey. Once again, the cohort was predominantly male $(85.2 \%)$, just over three quarters $(77.6 \%)$ said their first language was English and the vast majority (97.9\%) were between 17 and 25 years; most $(84.1 \%)$ were between 17 and 20 .

Table 1: Gender, first language and age composition of the 2005 and 2007 cohorts (including Business students)

\begin{tabular}{|c|c|c|c|c|c|c|c|}
\hline \multirow{2}{*}{} & \multicolumn{2}{c|}{2005} & \multicolumn{2}{c|}{2007} & \multicolumn{2}{c|}{ Total } \\
\cline { 3 - 8 } & $\mathrm{n}$ & $\%$ & $\mathrm{n}$ & $\%$ & $\mathrm{n}$ & $\%$ \\
\hline \multirow{3}{*}{$\begin{array}{c}\text { Gender } \\
\text { First }\end{array}$} & Female & 155 & 37.7 & 43 & 14.8 & 198 & 28.2 \\
\cline { 2 - 8 } language & Male & 256 & 62.3 & 248 & 85.2 & 504 & 71.8 \\
\cline { 2 - 8 } & English & 287 & 69.7 & 225 & 77.6 & 512 & 72.9 \\
\hline \multirow{3}{*}{\begin{tabular}{c} 
Agge \\
\cline { 2 - 8 }
\end{tabular}} & Other & 125 & 30.3 & 65 & 22.4 & 190 & 27.1 \\
\cline { 2 - 8 } & $20-25$ & 228 & 55.3 & 243 & 84.1 & 471 & 67.2 \\
\cline { 2 - 8 } & $26-35$ & 36 & 33.5 & 40 & 13.8 & 178 & 25.4 \\
\cline { 2 - 8 } & $>35$ & 10 & 2.4 & 1 & 0.3 & 11 & 1.6 \\
\hline
\end{tabular}


The difference in enrolments is possibly responsible for the difference in cohorts: the 2007 cohort was more predominantly male (chi-square, corrected $=44.261, \mathrm{df}=1, \mathrm{p}=.000$ ), younger (chi-square, corrected $=$ $65.675, \mathrm{df}=3, \mathrm{p}=.000$ ) and with more students whose first language was English (chi-square, corrected $=5.416$, $\mathrm{df}=1, \mathrm{p}=.020$ ). To annul this difference, Business students can be excluded from the 2005 cohort (leaving a much smaller sample of 387 students-96 students in 2005, 291 in 2007).

Table 2: Gender, first language and age composition of the 2005 and 2007 cohorts (excluding Business students)

\begin{tabular}{|c|c|c|c|c|c|}
\hline \multirow{2}{*}{\multicolumn{2}{c|}{}} & \multicolumn{2}{|c|}{2005} & \multicolumn{2}{c|}{2007} \\
\cline { 3 - 6 } & $\mathrm{n}$ & $\%$ & $\mathrm{n}$ & $\%$ \\
\hline \multirow{3}{*}{$\begin{array}{c}\text { Gender } \\
\text { First }\end{array}$} & Female & 9 & 9.4 & 43 & 14.8 \\
\cline { 2 - 6 } language & Male & 87 & 90.6 & 248 & 85.2 \\
\hline \multirow{3}{*}{\begin{tabular}{c} 
Age \\
\cline { 2 - 6 }
\end{tabular}} & English & 75 & 78.1 & 225 & 77.6 \\
\cline { 2 - 6 } & Other & 21 & 21.9 & & 84.1 \\
\cline { 2 - 6 } & $20-25$ & 76 & 79.2 & 243 & 13.8 \\
\cline { 2 - 6 } & $26-35$ & 3 & 17.7 & 5 & 1.7 \\
\hline
\end{tabular}

The similarity in discipline enrolment (that is, all students commencing Engineering) creates similar cohorts: there are no significant differences in composition in relation to gender (chi-square, corrected $=1.811$, $\mathrm{df}=1, \mathrm{p}=$ .178 ), first language (chi-square, corrected $=.012, \mathrm{df}=1, \mathrm{p}=.912$ ) or age group (chi-square, corrected $=1.945, \mathrm{df}=3, \mathrm{p}=.584$ ). Results for both cohort types - the larger one including Business students, and the smaller one excluding them-will be reported in relation to how students' behaviours may have changed between 2005 and 2007.

\section{Access to and use of the Internet for learning}

Students in both cohorts were asked about their access to the Internet off campus: 2005 students were asked "Do you have access to the Internet outside University?" and 2007 students were asked a slightly different question because they completed the survey when they were very new to the University: "Will you have access to the Internet outside University this semester?" Students in both cohorts were overwhelmingly clear in their answers: as shown in Table 3 the vast majority indicated that they had or believed they would have access to the Internet off campus, with more students indicating that they were unsure in 2007-possibly because of the earlier use of the survey (chi-square, corrected $=14.883, \mathrm{df}=2, \mathrm{p}=.001$ ).

Students were also asked about their use of the Internet for learning, again in items with different wording: 2005 students were asked "Do you frequently use online resources to help your learning?" and 2007 students 
were asked a slightly different question: "Do you frequently use online resources for study purposes?" Table 4 shows that the vast majority use the Web for learning related purposes, although there were differences in the 2007 cohort: fewer said they used web resources for study-this may be due to change in wording of the item, and again the timing of the survey (chi-square, corrected $=9.968, \mathrm{df}=2, \mathrm{p}=.000$ ). It may also be explained by the $4.8 \%$ in 2007 who were still unsure about their off campus access (given the early administration of the survey).

Table 3: Off campus access to the Internet

\begin{tabular}{|c|c|c|}
\hline \multirow{2}{*}{$\begin{array}{c}\text { Off campus } \\
\text { access }\end{array}$} & $\begin{array}{c}2005 \\
\text { Do you have access to the Internet } \\
\text { outside University? }\end{array}$ & $\begin{array}{c}\text { Will you have access to the Internet } \\
\text { outside University this semester? }\end{array}$ \\
\hline No & $21(5.1 \%)$ & $11(3.8 \%)$ \\
\hline Yes & $389(94.4 \%)$ & $265(91.4 \%)$ \\
\hline Not sure & $2(0.5 \%)$ & $14(4.8 \%)$ \\
\hline
\end{tabular}

Table 4: Use of the Web for learning

\begin{tabular}{|c|c|c|}
\hline $\begin{array}{c}\text { Web resources for } \\
\text { learning }\end{array}$ & $\begin{array}{c}2005 \\
\text { Do you frequently use online } \\
\text { resources to help your learning? }\end{array}$ & $\begin{array}{c}\text { Do you frequently use online } \\
\text { resources for study purposes? }\end{array}$ \\
\hline No & $14(3.4 \%)$ & $23(7.9 \%)$ \\
\hline Yes & $383(93.4 \%)$ & $251(86.6 \%)$ \\
\hline Not sure & $13(3.2 \%)$ & $16(5.5 \%)$ \\
\hline
\end{tabular}

When Business students are excluded from the first cohort, there was no difference in Engineering students' access to the Internet off-campus ( $p>$ $.05)$, but the difference in the use of the Web remains-students in 2007 were less likely to say they used the Web for learning (chi-square, corrected $=7.341, \mathrm{df}=2, \mathrm{p}=.025)$. Nevertheless, it is clear from these results that the vast majority of students in both cohorts had access or believed they would have access to the Internet off campus, and that they would use it for learning purposes. This is reassuring for those teaching these students: the vast majority of students have access and use it for learning.

\section{Ownership of devices}

Students in both cohorts were asked about their ownership of four devices: laptops, handhelds (PDAs), mobile phones and music playing devices such as iPods and MP3 players. Table 5 shows that just less than half the students in each cohort owned laptops, very small percentages reported ownership of handhelds $(<10 \%)$, whilst the vast majority owned mobile phones $(>96 \%)$. There was no indication of difference in ownership levels of these devices for the two cohorts, either when Business students were included or excluded $(p>.05)$. As expected, there was a change in the levels of 
ownership of iPods and MP3 players. In 2005, two fifths of students (40.6\%) owned a music playing device; in 2007, over two-thirds of students $(70.1 \%)$ owned them (chi-square, corrected $=65.296, \mathrm{df}=2, \mathrm{p}=.000$ ).

Table 5: Number and percentage of students who reported owning devices

\begin{tabular}{|l|c|c|c|c|c|}
\hline & Year & $\mathrm{n}$ & No & Yes & Not sure \\
\hline \multirow{2}{*}{ Laptop } & 2005 & 412 & $51.9 \%$ & $47.6 \%$ & $0.5 \%$ \\
\cline { 2 - 6 } & 2007 & 290 & $50.0 \%$ & $48.6 \%$ & $1.4 \%$ \\
\hline \multirow{2}{*}{$\begin{array}{l}\text { Handheld } \\
\text { Momputer }\end{array}$} & 2005 & 409 & $91.0 \%$ & $8.1 \%$ & $1.0 \%$ \\
\cline { 2 - 6 } & 2007 & 288 & $93.1 \%$ & $5.6 \%$ & $1.4 \%$ \\
\hline \multirow{2}{*}{ iPod or MP3 } & 2005 & 412 & $2.2 \%$ & $97.6 \%$ & $0.2 \%$ \\
\cline { 2 - 6 } & 2007 & 289 & $3.1 \%$ & $96.2 \%$ & $0.7 \%$ \\
\cline { 2 - 6 } & 2005 & 409 & $59.2 \%$ & $40.6 \%$ & $0.2 \%$ \\
\hline
\end{tabular}

These results suggest that teachers of incoming undergraduates, particularly those in Business and Engineering, can assume that the majority of students now own mobile phones and music playing devices such as $i$ Pods, about half have laptops, and very few have handhelds.

\section{Use of emerging communications tools}

Students in both cohorts were asked about their use of instant messaging applications (such as MSN Messenger), blogs and podcasting. Table 6 shows that the majority of students used instant messaging $(>82 \%)$, with significant growth $(\mathrm{p}<.05)$ in the use of blogs and podcasting by 2007 (29.8\% of students using blogs and $21.5 \%$ using podcasts).

Table 6: Percentage of students in 2005 and 2007 using emerging communications tools

\begin{tabular}{|l|c|c|c|c|}
\hline & Year & $\mathrm{n}$ & No & Yes \\
\hline \multirow{3}{*}{ Instant messaging } & 2005 & 412 & $17.7 \%$ & $82.3 \%$ \\
\cline { 2 - 5 } & 2007 & 286 & $12.0 \%$ & $87.8 \%$ \\
\hline \multirow{3}{*}{ Blogs } & 2005 & 411 & $79.3 \%$ & $20.7 \%$ \\
\cline { 2 - 5 } & 2007 & 285 & $70.2 \%$ & $29.8 \%$ \\
\hline Podcasts & 2005 & 410 & $93.4 \%$ & $6.6 \%$ \\
\cline { 2 - 5 } & 2007 & 284 & $78.5 \%$ & $21.5 \%$ \\
\hline
\end{tabular}

As indicated previously, the 2007 students were also asked how often they used these tools and whether they used them for study purposes. Table 7 shows that over half the students $(57.4 \%)$ were frequent users of instant messaging and $44.4 \%$ used it often or occasionally for study purposes; few students $(7.3 \%)$ were frequent users of blogs and $20 \%$ used them often or occasionally for study purposes; and just over one fifth $(21.1 \%)$ were frequent users of podcasts and $31.8 \%$ used them often or occasionally for study purposes. 
Table 7: 2007 students' frequency of use and for study purposes of emerging communications tools

\begin{tabular}{|l|c|c|c|c|c|c|c|c|c|}
\hline & \multicolumn{4}{|c|}{ Frequency of use } & \multicolumn{5}{c|}{ Frequency of use for study } \\
\cline { 2 - 11 } & $\mathrm{n}$ & $\begin{array}{c}\text { Frequ- } \\
\text { ently }\end{array}$ & $\begin{array}{c}\text { Occas- } \\
\text { ionally }\end{array}$ & Rarely & $\mathrm{n}$ & Often & $\begin{array}{c}\text { Occas- } \\
\text { ionally }\end{array}$ & Rarely & Never \\
\hline $\begin{array}{l}\text { Instant } \\
\text { messaging }\end{array}$ & 258 & 57.4 & 33.7 & 8.9 & 259 & 7.7 & 36.7 & 42.1 & 13.5 \\
\hline Blogs & 96 & 7.3 & 50.0 & 41.7 & 95 & 2.1 & 17.9 & 37.9 & 42.1 \\
\hline Podcasts & 66 & 21.2 & 42.4 & 36.4 & 63 & 15.9 & 15.9 & 36.5 & 31.7 \\
\hline
\end{tabular}

These results suggest that many students are amenable to using instant messaging for study purposes, but use of blogs and podcasting for study purposes is less common at this stage.

\section{Discussion}

Studies of this nature have been plentiful in recent years (Caruso, 2004; Caruso \& Kvavik, 2005; Jones, 2002; Lenhart, Rainie, \& Lewis, 2001; Lenhart, Simon, \& Graziano, 2001; Oblinger \& Oblinger, 2005), particularly in the United States. The results reported here suggest that many Australian undergraduates own sophisticated portable devices (particularly mobile phones and music devices). Table 8 attempts to compare the findings of this research with two larger and quite similar studies, including one very large study by Caruso \& Kvavik from the United States in 2005 (bearing in mind anomalies are often created by differences in time, sample size and item wording-for example, the study by Kennedy et al. in 2006 asked about access rather than ownership).

Table 8: Comparison of results of this study with others about ownership of devices

\begin{tabular}{|l|c|c|c|c|}
\hline \multicolumn{1}{|c|}{$\begin{array}{c}\text { Authors and } \\
\text { year }\end{array}$} & $\begin{array}{c}\text { Caruso \& } \\
\text { Kvavik, 2005 }\end{array}$ & $\begin{array}{c}\text { This study, } \\
2005\end{array}$ & $\begin{array}{c}\text { Kennedy et al., } \\
2006\end{array}$ & $\begin{array}{c}\text { This study, } \\
2007\end{array}$ \\
\hline Location & United States & $\begin{array}{c}\text { Perth, } \\
\text { Australia }\end{array}$ & $\begin{array}{c}\text { Melbourne, } \\
\text { Australia }\end{array}$ & $\begin{array}{c}\text { Perth, } \\
\text { Australia }\end{array}$ \\
\hline Sample size & 18,039 & 365 & 2120 & 290 \\
\hline $\begin{array}{l}\text { Population of } \\
\text { interest }\end{array}$ & $\begin{array}{c}\text { College } \\
\text { students }\end{array}$ & $\begin{array}{c}\text { Beginning } \\
\text { undergrads }\end{array}$ & $\begin{array}{c}\text { Beginning } \\
\text { undergrads }\end{array}$ \\
\hline Laptop & $61.6 \%$ & $46.0 \%$ & $63.2 \%$ & $48.5 \%$ \\
\hline Handhelds & $12.6 \%$ & $8.3 \%$ & $10.8 \%$ & $5.5 \%$ \\
\hline Mobile phone & $\begin{array}{c}90.1 \%(\text { cell } \\
\text { phone); } 1.3 \% \\
\text { (smart phone) }\end{array}$ & $99.7 \%$ & $96.4 \%$ & $95.5 \%$ \\
\hline $\begin{array}{l}\text { iPod or MP3 } \\
\text { player }\end{array}$ & $38.4 \%$ & $41.6 \%$ & $68.9 \%$ & $69.4 \%$ \\
\hline
\end{tabular}


It would seem that ownership of devices is comparable in the United States given that Caruso and Kvavik's study was conducted in 2005 (Caruso \& Kvavik, 2005). In comparison to the study reported here in relation to the 2007 cohort, Kennedy et al. found in 2006 that a higher percentage of respondents had access to laptops and handhelds, and very similar levels of mobile phone and iPod or MP3 players. Kennedy et al. (2006) found that 98.6\% of their students had off campus Internet access which was comparable to the $94.4 \%$ (2005) and the $91.4 \%$ (2007) who had off campus access in this study. Results reported here suggest that this group of Australian undergraduates owns sophisticated portable devices (particularly laptops, mobile phones and music devices), and that many are frequent users of instant messaging, and many access blogs (and podcasts) even though this technology has only recently come to prominence in Australia (Cook, 2005).

It is important to note, in addition, that students are likely to carry with them other devices not mentioned here (gaming devices, for example), and they are likely to use their devices for multiple functions, many of which are not investigated here (listening to music and playing movies, for example). There is also no doubt that much of undergraduates' technology related activity is not directly linked to their education. Many mobile devices listed in this study are primarily for social or entertainment purposes. This is also true of the activities conducted on the emerging communications tools. For example only $6.5 \%$ of the incoming students have used blogs for study purposes (either often or occasionally) and the finding was similar for instant messaging (39.5\%) and podcasting (11.5\%). However, the percentages who used blogging and instant messaging for socialising were significantly higher $(29.6 \%$ and $86.3 \%$ respectively). Nevertheless, it may be that that these primarily social devices and tools (carried by a high proportion of students) might well be used for educational purposes, particularly if their use is suggested as part of course work and learning activities in and beyond the classroom.

However, there is a gap to be bridged in this matter: even though undergraduate students own and use emerging technologies and tools, their university teachers are less likely to do so: the gap between the digital habits of students and teachers has been growing for some time (Smith \& Curtin, 1997). This is likely to be exacerbated by an aging workforce in Australian higher education: Hugo reports that "the Australian university teaching workforce is concentrated in the older age groups more than not only the total workforce but also the total professional workforce" and, according to 2001 census figures, over $60 \%$ of teaching academics in Australian universities were over 45 years of age (Hugo, 2004). Research shows that ownership and use of information and communication technologies tend to decrease with age (White, 2007); greater use of the 
Internet in Australian households is highest among the young, and generally decreases with age (Australian Bureau of Statistics, 2005-06). It is feasible to assume, then that current university teachers are likely to be using fewer emerging technologies than their students, and therefore even less likely to want to initiate their use in the classroom. Unlike their 'digital native' students, they are known as 'digital immigrants' (Prensky, 2001), and as such they have had to learn and adapt to using the new technologies rather than seeing them as 'natural' tools that were always a part of their world. Additionally, the teaching and learning styles that middle aged university teachers find intellectually stimulating are unlikely to maintain the interest of today's "Net Genners" (Moore, Moore \& Fowler, 2005). In contrast to many of their teachers, the "Net Genners" are typically intuitive visual communicators who can integrate virtual and physical environments, learn better through discovery than by absorption, respond quickly to visual stimulus, and shift attention rapidly, particularly if they feel bored (Oblinger \& Oblinger, 2005). They are 'doers' rather than 'knowledge acquisitors' and they know that knowledge is constantly changing. So, for these students 'results and actions are considered more important than the accumulation of facts' (Oblinger, 2003). Frand claims that the digital natives are more likely to use 'Nintendo over Logic': many apply the techniques of learning computer games to their formal learning-try something and if it fails, try again. He warns that 'until the nature of the educational relationships change in the classroom and at the institutional level, we will not realize the full value of the computer, communication, and information technology investments that we are making today' (Frand, 2000).

One clear solution to bridging this gap is to encourage teaching staff to familiarise themselves with the possible contents of their students' digital backpacks. Staff development seminars, offered in non-threatening and relaxed contexts (and possibly sponsored by emerging technology providers) are one way of having staff explore emerging mobile devices. Such sessions can include pedagogical input and sharing of ideas (among staff and students as well) as to how emerging tools and particularly the interactivity and engagement that they allow might be used to engage students and enhance learning. Key strategies are to review teaching and learning practices, and design experiences to engage the learner (in general, moving away from didactic content delivery and increasing discursive interaction) (Kukulska-Hulme \& Traxler, 2005). This, of course, is at the heart of sound university pedagogy, regardless of the environment (Mentkowski, 2000; Ramsden, 1992). What is expected is that a teacher always aims to create an engaging learning environment and this should not involve adapting to the available technology but vice versa (Hoppe et. al 2003). Learning management systems such as Blackboard and WebCT have gone some way to providing more interactive virtual learning experiences 
using tools such as quizzes, for example. However, given the Net Generation's experiences in engaging and interacting in electronic communications (particularly in games), low level interactivity in a learning management system is unlikely to stimulate a sense of connectedness for the learner. Emerging, browser based collaborative tools, incorporating synchronous audio, video, chat and data display, such as Elluminate (www.elluminate.com) and Vyew (http:/ / www.vyew.com) are likely to offer greater engagement.

However, university adoption of institution-wide technologies is rarely a hasty process (Bates, 2000). To circumvent waiting for a whole of institution response to adopting new technologies, university teachers can encourage the use of student-owned devices and student-used modes of communication where they can enhance students' engagement, where access to technologies is equitable for students, and where the use of online applications poses little risk to institutions. Nevertheless, teachers must be mindful that (as found by Kennedy et al. and again in the studies reported here) although the majority of incoming students are techno-literate and are regularly using emerging devices, there is still a significant proportion who are not, and students need to be educated in the proper use (and associated risks) of tools such as blogs and podcasts. Moreover, the fact that students own devices and use social software tools for social purposes does not mean that they will necessarily transfer those behaviours to the learning context. This suggests that teachers who wish to encourage their students to use their personal devices for learning need to do so with some sensitivity, and by providing a structure and rationale for their use.

\section{Conclusion}

Results reported here suggest that, like their North American peers, Australian undergraduates (at least in the two disciplines considered here) have a high level of access to the Internet off campus, and use web resources for learning. They have a very high level of ownership of mobile phones and music playing devices; about half of them have laptops (and relatively few have handheld computers). All of these devices can be used "on the go" for interactivity through instant messaging, blogging and podcasting as well as a host of other Web 2.0 applications not considered in detail here. Laurillard claims that academic knowledge is best achieved in university learning experiences which are dialogic (between teacher and learner, or learner and learner) and which involve exposition, argument, interpretation, and reflection on experience of the world (Laurillard, 2002). Emerging technologies owned and used by students, and incorporated wisely into university curricula, can go some way towards enhancing high quality, face to face learning experiences, where articulated knowledge is 
constructed and student achievement of intellectually challenging outcomes is effected. Exposition, argument, interpretation, and reflection are all activities which can be undertaken in traditional face to face classrooms, or perhaps as easily for digital natives using the devices stored in their digital backpacks. Those devices appear to be getting smaller and smarter, and more prevalent. Therein lies an opportunity for the enterprising university teacher: use students' mobile devices and social software applications, and challenge them to go beyond their use purely for social ends, and use them to be participative constructors of knowledge in engaging learning experiences.

\section{References}

Apple. (2007). Introducing iPhone. [viewed 14 Mar 2007] http:/ / www.apple.com/iphone/

Australian Bureau of Statistics (2005-06). Household Use of Information Technology. Canberra. [verified 6 Apr 2006] http:/ / www.abs.gov.au/ Ausstats / abs@.nsf/0/acc2d18cc958bc7bca2568a9001393ae?OpenDocument

Bates, A. W. T. (2000). Managing technological change: Strategies for college and university leaders. San Francisco: Jossey-Bass.

Caruso, J. B. (2004). ECAR study of students and information technology, 2004: Convenience, connection, and control. EDUCAUSE. http:/ / www.educause.edu/ir/library/pdf/ERS0405/ekf0405.pdf

Caruso, J. B. \& Kvavik, R. B. (2005). ECAR study of students and information technology, 2005: Convenience, connection, control, and learning. EDUCAUSE. http:/ / www.educause.edu/ content.asp?PAGE_ID=8964\&bhcp=1

Cochrane, T. (2006). Learning with wireless mobile devices and social software. Proceedings ASCILITE 2006, 3-6 December, Sydney. http: / / www.ascilite.org.au / conferences/sydney06/proceeding/pdf_papers/p50.pdf

Cook, T. (2005). State-of-play: Blogging and podcasting in Australia today. [viewed 19 Apr 2005] http: / / www.onlineopinion.com.au / view.asp?article=3307

Cych, L. (2006). Social networks. Emerging Technologies for Learning. [viewed 1 Mar 2007] http:/ / www.becta.org.uk/ corporate/ publications /

Deneen, L. (2001). Handheld PDAs and wearable computing devices. [viewed 1 Dec 2001, verified 7 Apr 2007] http:/ / www.educause.edu/ir/library/pdf/DEC0101.pdf

Frand, J. L. (2000). The information-age mindset: Changes in students and implications for higher education. EDUCAUSE, September/October, 15-24. [verified 7 Apr 2007] http:/ / www.educause.edu/ir/library/pdf/ERM0051.pdf

Heppell, S. (2002). Thoughts and follow-ups. [viewed 1 Mar 2007]

http:/ / rubble.heppell.net/broadcasting/ contents.html 
Huba, M. E., \& Freed, J. E. (2000). Learner-centred assessment on college campuses: Shifting the focus from teaching to learning. Boston: Allyn and Bacon.

Hugo, G. (2004). The demography of Australia's academic workforce: Patterns, problems and policy implications. Paper presented at the Monash Seminars on Higher Education, Monash University, 7 September 2004. [verified 7 Apr 2007] http://www.atn.edu.au/docs/Demography_Australias_Academic_Workforce.pdf

Jones, S. (2002). The Internet goes to college: How students are living in the future with today's technology. Washington DC: Pew Internet \& American Life Project. [verified 7 Apr 2007] http:/ / www.pewinternet.org/pdfs/PIP_College_Report.pdf

Kennedy, G., Krause, K.-L., Judd, T., Churchward, A. \& Gray, K. (2006). First year experiences with technology: Are they really digital natives? BMU, University of Melbourne. [verified 7 Apr 2007]

http:/ / www.bmu.unimelb.edu.au/research/munatives/natives_report2006.pdf

Kukulska-Hulme, A., \& Traxler, J. (2005). Mobile teaching and learning. In A. Kukulska-Hulme \& J. Traxler (Eds.), Mobile learning: A handbook for educators and trainers (pp. 25-44). London: Routledge.

Laurillard, D. (2002). Rethinking university teaching: A framework for the effective use of educational technology (2nd ed.). London: Routledge Palmer.

Lenhart, A., Rainie, L., \& Lewis, O. (2001). Teenage life online: The rise of the instantmessage generation and the Internet's impact on friendships and family relationships. Washinton DC: Pew Internet \& American Life Project. [verified 7 Apr 2007] http:/ / www.pewtrusts.org/pdf/vf_pew_internet_teens.pdf

Lenhart, A., Simon, M., \& Graziano, M. (2001). The Internet and education: Findings of the Pew Internet $\mathcal{E}$ American Life Project. Washington DC: Pew Internet \& American Life Project. [verified 7 Apr 2007] http: / / www.pewinternet.org/pdfs/PIP_Schools_Report.pdf

Mentkowski, M. (2000). Learning that lasts: Integrating learning, development, and performance in college and beyond. San Francisco: Jossey-Bass.

Millea, J., Green, I. \& Putland, G. (2005). Emerging technologies: A framework for thinking. Canberra: education.au limited. [verified 7 Apr 2007] http: / / www.det.act.gov.au/publicat/pdf/emergingtechnologies.pdf

Oblinger, D. G. \& Oblinger, J. L. (Eds.). (2005). Educating the net generation. EDUCAUSE. [verified 7 Apr 2007] http:/ / www.educause.edu/educatingthenetgen/

Oliver, B. \& Barrett, C. (2004). Comfort + ubiquity = adoption: Enhancing first year students' communication skills with handheld computers. Proceedings ASCILITE 2004, Perth. http:/ / www.ascilite.org.au/conferences/ perth04/procs/oliver-b.html

Prensky, M. (2001). Digital Natives, Digital Immigrants. On the Horizon, 9(5). [verified 7 Apr 2007] http: / / www.marcprensky.com/ writing/Prensky\%20$\%$ 20Digital\%20Natives,\%20Digital\%20Immigrants\%20-\%20Part1.pdf

Ramsden, P. (1992). Learning to teach in higher education. London: Routledge. 
RSS (file format) (2005). Wikipedia. [viewed 23 Oct 2005]

http: / / en.wikipedia.org/wiki/RSS_\%28file_format\%29

Smith, R. \& Curtin, P. (1997). Children, computers and life online: Education and the cyber-world. In I. Snyder (Ed.), Page to screen: Taking literacy into the electronic era (pp. 211-233). St Leonards, NSW: Allen \& Unwin.

Stanford University (2005). Stanford on iTunes. [viewed 2 Nov 2005] http: / / itunes.stanford.edu /

Trinder, J. (2005). Mobile technologies and systems. In A. Kukulska-Hulme \& J. Traxler (Eds.), Mobile learning: A handbook for educators and trainers (pp. 7-24). London: Routledge.

Wenger, E., McDermott, R. \& Snyder, W. (2002). Cultivating communities of practice: A guide to managing knowledge. Boston: Harvard Business School Press.

White, D. (2007). Results of the 'Online Tool Use Survey' undertaken by the JISC funded SPIRE project. [verified 7 Apr 2007] http:/ / tallblog.conted.ox.ac.uk/wpcontent/uploads/2007/03/survey-summary.pdf

\section{Appendix}

\begin{tabular}{|c|c|c|c|}
\hline \multicolumn{2}{|c|}{2005 Survey items } & \multicolumn{2}{|c|}{2007 Survey items } \\
\hline \multicolumn{2}{|c|}{ Demographics } & \multicolumn{2}{|c|}{ Demographics } \\
\hline What is your sex? & $\square$ Female & What is your sex? & $\square$ Female \\
\hline $\begin{array}{l}\text { What is your first } \\
\text { language? }\end{array}$ & $\begin{array}{l}\square \text { English } \square \text { Other } \\
\text { (please specify) }\end{array}$ & $\begin{array}{l}\text { What is your first } \\
\text { language? }\end{array}$ & $\begin{array}{l}\square \text { English } \square \text { Other } \\
\text { (please specify) }\end{array}$ \\
\hline $\begin{array}{l}\text { What is your age } \\
\text { group? }\end{array}$ & \begin{tabular}{|l|}
$\square<20 \quad \square 20-25 \quad \square$ \\
$26-35 \quad \square>35$
\end{tabular} & $\begin{array}{l}\text { What is your age } \\
\text { group? }\end{array}$ & $\begin{array}{l}\square<20 \quad \square 20-25 \quad \square 26- \\
35 \quad \square>35\end{array}$ \\
\hline
\end{tabular}

Access to internet and
use of web resources \begin{tabular}{|l|l|l|l|}
\hline $\begin{array}{l}\text { Do you have access } \\
\text { to the Internet outside } \\
\text { University? }\end{array}$ & $\begin{array}{l}\text { No/Yes/Not sure } \\
\text { (Circle one) }\end{array}$ & $\begin{array}{l}\text { Will you have access } \\
\text { to the Internet outside } \\
\text { University this } \\
\text { semester? }\end{array}$ & $\begin{array}{l}\text { No/Yes/Not sure (Circle } \\
\text { one) }\end{array}$ \\
\hline $\begin{array}{l}\text { Do you frequently use } \\
\text { online resources to } \\
\text { help your learning? }\end{array}$ & $\begin{array}{l}\text { No/Yes/Not sure } \\
\text { (Circle one) }\end{array}$ & $\begin{array}{l}\text { Do you frequently use } \\
\text { online resources for } \\
\text { study purposes? }\end{array}$ & $\begin{array}{l}\text { No/Yes/Not sure (Circle } \\
\text { one) }\end{array}$ \\
\hline
\end{tabular}

Ownership of devices

Ownership of devices

\begin{tabular}{|l|l|l|l|}
\hline $\begin{array}{l}\text { Do you have a laptop } \\
\text { computer (also known } \\
\text { as a notebook)? }\end{array}$ & $\begin{array}{l}\text { No/Yes/Not sure } \\
\text { (Circle one) }\end{array}$ & $\begin{array}{l}\text { Do you have a laptop } \\
\text { computer? }\end{array}$ & $\begin{array}{l}\text { No/Yes/Not sure (Circle } \\
\text { one) }\end{array}$ \\
\hline
\end{tabular}




\begin{tabular}{|l|l|l|l|}
\hline $\begin{array}{l}\text { Do you have a } \\
\text { handheld computer } \\
\text { (also known as a } \\
\text { PDA, Palm Pilot etc)? }\end{array}$ & $\begin{array}{l}\text { No/Yes/Not sure } \\
\text { (Circle one) }\end{array}$ & $\begin{array}{l}\text { Do you have a } \\
\text { handheld computer } \\
\text { (also known as a } \\
\text { PDA, Palm Pilot etc)? }\end{array}$ & $\begin{array}{l}\text { No/Yes/Not sure (Circle } \\
\text { one) }\end{array}$ \\
\hline $\begin{array}{l}\text { Do you have a mobile } \\
\text { phone? }\end{array}$ & $\begin{array}{l}\text { No/Yes/Not sure } \\
\text { (Circle one) }\end{array}$ & $\begin{array}{l}\text { Do you have a mobile } \\
\text { phone? }\end{array}$ & $\begin{array}{l}\text { No/Yes/Not sure (Circle } \\
\text { one) }\end{array}$ \\
\hline $\begin{array}{l}\text { Do you have an iPod } \\
\text { or MP3 player? }\end{array}$ & $\begin{array}{l}\text { No/Yes/Not sure } \\
\text { (Circle one) }\end{array}$ & $\begin{array}{l}\text { Do you have an iPod } \\
\text { or MP3 player? }\end{array}$ & $\begin{array}{l}\text { No/Yes/Not sure (Circle } \\
\text { one) }\end{array}$ \\
\hline
\end{tabular}

Use of communication tools

Use of communication tools

Which (if any) of the following communication Which (if any) of the following communication

tools do you use? Several of these are recent tools do you use? Several of these are recent

developments; you may not have heard of developments; you may not have heard of

them. them.

\begin{tabular}{|c|c|c|c|}
\hline \multirow[t]{3}{*}{$\begin{array}{l}\text { Do you use instant } \\
\text { message software } \\
\text { such as MSN } \\
\text { messenger? }\end{array}$} & No/ Yes & $\begin{array}{l}\text { Do you use instant } \\
\text { message software } \\
\text { such as MSN } \\
\text { messenger? }\end{array}$ & No /Yes (Circle one) \\
\hline & & If yes, how often? & $\begin{array}{l}\text { Frequently/Occasionally/ } \\
\text { Rarely (Circle one) }\end{array}$ \\
\hline & & $\begin{array}{l}\text { If yes, do you use it } \\
\text { for study purposes? }\end{array}$ & $\begin{array}{l}\text { Often/ Occasionally/ } \\
\text { Rarely/Never (Circle } \\
\text { one) }\end{array}$ \\
\hline \multirow[t]{3}{*}{ Do you use a blog? } & $\mathrm{No} / \mathrm{Yes}$ & $\begin{array}{l}\text { Do you read or write } \\
\text { blogs? }\end{array}$ & No / Yes \\
\hline & & $\begin{array}{l}\text { If yes, how often? } \\
\text { (Circle one) }\end{array}$ & $\begin{array}{l}\text { Frequently/ } \\
\text { Occasionally/ Rarely }\end{array}$ \\
\hline & & $\begin{array}{l}\text { If yes, do you use } \\
\text { them for study } \\
\text { purposes? }\end{array}$ & $\begin{array}{l}\text { Often/ Occasionally/ } \\
\text { Rarely/Never }\end{array}$ \\
\hline \multirow[t]{3}{*}{$\begin{array}{l}\text { Do you send or } \\
\text { receive podcasts? }\end{array}$} & No/ Yes & $\begin{array}{l}\text { Do you send or } \\
\text { receive podcasts? }\end{array}$ & No / Yes \\
\hline & & $\begin{array}{l}\text { If yes, how often? } \\
\text { (Circle one) }\end{array}$ & $\begin{array}{l}\text { Frequently/ } \\
\text { Occasionally/ Rarely }\end{array}$ \\
\hline & & $\begin{array}{l}\text { If yes, do you use } \\
\text { them for study } \\
\text { purposes? }\end{array}$ & $\begin{array}{l}\text { Often/ Occasionally/ } \\
\text { Rarely/Never }\end{array}$ \\
\hline
\end{tabular}

Beverley Oliver and Veronica Goerke

Learning Support Network

Curtin University of Technology

Email: b.oliver@curtin.edu.au, v.goerke@curtin.edu.au

Contact author: Dr Beverley Oliver

Manager, Teaching Development Unit

Learning Support Network

Curtin University of Technology

GPO Box U1987, Perth WA 6845, Australia 